\title{
Decreased oxygen extraction during cardiopulmonary exercise test in patients with chronic fatigue syndrome
}

\author{
Ruud CW Vermeulen ${ }^{*}$ and Ineke WG Vermeulen van Eck
}

\begin{abstract}
Background: The insufficient metabolic adaptation to exercise in Chronic Fatigue Syndrome (CFS) is still being debated and poorly understood.

Methods: We analysed the cardiopulmonary exercise tests of CFS patients, idiopathic chronic fatigue (CFI) patients and healthy visitors. Continuous non-invasive measurement of the cardiac output by Nexfin" (BMEYE B.V. Amsterdam, the Netherlands) was added to the cardiopulmonary exercise tests. The peak oxygen extraction by muscle cells and the increase of cardiac output relative to the increase of oxygen uptake $\left(\Delta Q^{\prime} / \Delta V^{\prime} \mathrm{O}_{2}\right)$ were measured, calculated from the cardiac output and the oxygen uptake during incremental exercise.

Results: The peak oxygen extraction by muscle cells was $10.83 \pm 2.80 \mathrm{ml} / 100 \mathrm{ml}$ in 178 CFS women, $11.62 \pm 2.90 \mathrm{ml} /$ $100 \mathrm{ml}$ in $172 \mathrm{CFl}$, and $13.45 \pm 2.72 \mathrm{ml} / 100 \mathrm{ml}$ in 11 healthy women (ANOVA: $P=0.001$ ), $13.66 \pm 3.31 \mathrm{ml} / 100 \mathrm{ml}$ in 25 CFS men, $14.63 \pm 4.38 \mathrm{ml} / 100 \mathrm{ml}$ in $51 \mathrm{CFl}$, and $19.52 \pm 6.53 \mathrm{ml} / 100 \mathrm{ml}$ in 7 healthy men (ANOVA: $P=0.008$ ). The $\Delta \mathrm{Q}^{\prime} / \Delta \mathrm{V}^{\prime} \mathrm{O}_{2}$ was $>6 \mathrm{~L} / \mathrm{L}$ (normal $\Delta \mathrm{Q}^{\prime} / \Delta \mathrm{V}^{\prime} \mathrm{O}_{2} \approx 5 \mathrm{~L} / \mathrm{L}$ ) in $70 \%$ of the patients and in $22 \%$ of the healthy group.

Conclusion: Low oxygen uptake by muscle cells causes exercise intolerance in a majority of CFS patients, indicating insufficient metabolic adaptation to incremental exercise. The high increase of the cardiac output relative to the increase of oxygen uptake argues against deconditioning as a cause for physical impairment in these patients.
\end{abstract}

Keywords: Chronic fatigue syndrome, Exercise test, Exercise intolerance, Oxygen extraction

\section{Background}

Exercise intolerance is a frequent complaint from patients who meet the criteria for Chronic Fatigue Syndrome/ Myalgic Encephalitis (CFS) and Idiopathic Chronic Fatigue (CFI) [1].

Objective tests for physical impairment measure the maximal oxygen uptake (peak $\mathrm{V}^{\prime} \mathrm{O}_{2}$ ) during a cardiopulmonary exercise test (CPET) [2-4]. Most studies agree that peak $\mathrm{V}^{\prime} \mathrm{O}_{2}$ is lower in CFS, but we need to understand the cause of the lower peak $\mathrm{V}^{\prime} \mathrm{O}_{2}$ to explain the pathogenesis.

The $\mathrm{V}^{\prime} \mathrm{O}_{2}$ depends on the uptake, transport and metabolism of oxygen in the muscle cells during physical exercise. In most CPET studies in CFS patients, the limitation of peak $\mathrm{V}^{\prime} \mathrm{O}_{2}$ is not attributed to a lower uptake

\footnotetext{
* Correspondence: rv@cvscentrum.n!

CFS/ME Medical Centre Amsterdam, Waalstraat 25-31, Amsterdam 1078BR, Netherlands
}

and transport of oxygen to the muscle. A lower metabolic capacity of the muscle cell would change the demand for oxygen and thus lower the oxygen extraction $\left(\mathrm{C}(\mathrm{a}-\mathrm{v}) \mathrm{O}_{2}\right)$ and increase the cardiac output relative to $\mathrm{V}^{\prime} \mathrm{O}_{2}\left(\Delta \mathrm{Q}^{\prime} / \Delta \mathrm{V}^{\prime} \mathrm{O}_{2}\right)[5,6]$. In previous studies we, and others, did not find impaired mitochondrial activity to be a cause for a lower peak $\mathrm{V}^{\prime} \mathrm{O}_{2}[4,7]$, but abnormal mitochondrial activity was reported by some in CFS and CFI [8-10].

The aim of the present retrospective study was to determine to what extent the physical impairment in CFS and CFI was attributable to changes in uptake, transport and metabolism of oxygen in the muscle cells.

\section{Methods}

Data was collected from patients who attended the CFS Medical Centre Amsterdam. The data of sedentary men and women, physically active less than 1 hour per week, 
was added to the patient database. This group comprised visitors to the centre for cardiopulmonary exercise tests, check-ups and training program advice over the same period. We obtained information about the health status of this group, but laboratory tests were not included. Subjects using medication that could possibly influence the pulmonary, cardiovascular, immunologic system or cellular respiration were not included in the study. Chronic fatigue patients were assigned to the CFS or CFI group according to the criteria of Fukuda [1]. Operational criteria for assignment were: a score of $>40$ on the fatigue subscale of the Checklist Individual Strength (CIS-20) [11], score of $\leq 35$ for vitality, $\leq 62.5$ for Social Functioning and $\leq 50$ for Role-Physical on the SF-36 [12] and $\geq 4$ positive scores $(\geq 7,5)$ of the additional symptoms of the CDC Symptom Inventory -DLV [13] for the diagnosis of CFS and $\leq 4$ positive scores $(\geq 7,5)$ of the additional symptoms of the CDC Symptom Inventory -DLV for the diagnosis of idiopathic chronic fatigue (CFI) . The cognitive function of patients was screened with the Shifting Attentional Test Visual of the Amsterdam Neuropsychological Tasks [14]. Normal Z-score in this test is -2 to +2 .

All patients completed a CPET as part of the diagnostic procedure. The protocol of the CPET was described before [4]. All subjects performed a symptom limited CPET on a cycle ergometer (Excalibur, Lode, Groningen, The Netherlands) as described by Wassermann et al. [15]: 3 min without activity, 3 min of unloaded pedalling, followed by cycling against increasing resistance until exhaustion (ramp protocol) and concluded by 3 min cycling without resistance. The work rate increase was estimated from history, physical examination, gender, weight and height. Verbal encouragement was used to maximise performance during the last phase of incremental exercise. Exhaustion of the leg muscles was the limiting symptom in all participants. The V'E, V'O2, $\mathrm{V}^{\prime} \mathrm{CO}_{2}$ and oxygen saturation were continuously measured (Metasoft). The ECG was continuously recorded and blood pressure was measured every 2 min. Maximal exercise capacity was expressed as peak oxygen uptake per kilogram bodyweight and as percentage of predicted maximal oxygen uptake [16]. Non-invasive stroke volume measurement by continuous beat-to-beat pulse contour analysis (Nexfin) was added to the standard measurements of the CPET [17]. Oxygen extraction and $\Delta \mathrm{Q}^{\prime} / \Delta \mathrm{V}^{\prime} \mathrm{O}_{2}$ were calculated from the oxygen uptake and the cardiac output $\left(\mathrm{C}(\mathrm{a}-\mathrm{v}) \mathrm{O}_{2}=\right.$ $100 \times \mathrm{V}^{\prime} \mathrm{O}_{2} / \mathrm{CO}$ and (Q'max-Q'rest) $/\left(\mathrm{V}^{\prime} \mathrm{O}_{2}\right.$ max-V' $\mathrm{V}_{2} \mathrm{O}_{2}$ rest) $)$ [18]. All subjects signed an informed consent for the use of the data for analysis and publication.

Statistical analysis was conducted using the IBM Statistical Package for the Social Sciences (19.0 for Windows, Chicago, Ill, US). The results were presented as the mean \pm standard deviation (SD). Kolmogorov-Smirnov tests with Lilliefors significance correction for normality showed that the data were normally distributed. Differences between groups were tested with Analysis of Variance (ANOVA) and Bonferroni post hoc analysis. Pearson product-moment correlation coefficient was calculated as a measure of the strength of the relationship between 2 variables. Statistical significance of two-tailed tests was determined by an alpha level of 0.05 .

\section{Results}

Data was collected and analysed from a total of 444 subjects who visited the CFS/ME Medical Centre Amsterdam between June 2008 and June 2013: 203 CFS patients (178 women), 223 CFI patients (172 women) and 18 healthy visitors (11 women) (Table 1).

Post hoc Bonferroni analysis revealed that the body weight of healthy males was higher than the body weight of male CFI patients ( $P=0.036,95 \%$ CI: $0.70 ; 27.95)$.

Haemoglobin was not different in CFS and CFI patients (Table 1). In female patients haemoglobin was not related to $\mathrm{O} 2$ extraction $(\mathrm{r}=0.077, P=0.155)$ or to the increase of cardiac output relative to oxygen uptake $\left(\Delta \mathrm{Q}^{\prime} / \Delta \mathrm{V}^{\prime} \mathrm{O}_{2}\right)(\mathrm{r}=-0.008, P=0.882)$. In male patients haemoglobin was related to $\mathrm{O} 2$ extraction $(\mathrm{r}=0.245$, $P=0.047)$ but not to $\Delta \mathrm{Q}^{\prime} / \Delta \mathrm{V}^{\prime} \mathrm{O}_{2}(\mathrm{r}=-0.140, P=0.273)$.

The pulmonary ventilation tests showed no difference between the CFS, CFI and healthy groups (data not shown) and the cardiac index was similar in the groups at any time during the CPET. Blood pressure was within normal limits in all tests.

At the anaerobic threshold, $\mathrm{O}_{2}$ extraction in healthy women was higher than in CFS $(P=0.008,95 \%$ CI: 0.378 ; 3.273). The $\mathrm{O}_{2}$ extraction in healthy men was higher than in CFS $(P=0.044,95 \%$ CI: $0.064 ; 6.221)$ and higher than in CFI ( $P=0.023,95 \%$ CI: $0.355 ; 6.172)$.

At peak exercise $\mathrm{O}_{2}$ extraction was higher in healthy women than in CFS $(P=0.010,95 \%$ CI: $0.49 ; 4.74)$ and higher in CFI than in CFS $(P=0.030,95 \% \mathrm{CI}$ : 0.06; 1.52). The $\mathrm{O}_{2}$ extraction was higher in healthy men than in CFS $(P=0.006,95 \%$ CI: $1.36 ; 10.36)$ and higher than in CFI $(P=0.018,95 \%$ CI: 0.65 ; 9.13).

The lowest level of $\mathrm{O}_{2}$ extraction at maximal workload was $10.0 \mathrm{ml} / 100 \mathrm{ml}$ in the group of healthy women, $5.4 \mathrm{ml} / 100 \mathrm{ml}$ in CFI and $4.4 \mathrm{ml} / 100 \mathrm{ml}$ in female CFS patients. The lowest $\mathrm{O}_{2}$ extraction at maximal workload in males was $12.5 \mathrm{ml} / 100 \mathrm{ml}$ in the healthy group, $8.2 \mathrm{ml} /$ $100 \mathrm{ml}$ in the CFI and $6.9 \mathrm{ml} / 100$ in CFS patients.

The increase of cardiac output relative to oxygen uptake $\left(\Delta \mathrm{Q}^{\prime} / \Delta \mathrm{V}^{\prime} \mathrm{O}_{2}\right)$ was lower in healthy women than CFS $(P=0.011,95 \%$ CI: $0.45 ; 4.72)$ and in healthy men than CFS ( $P=0.037,95 \%$ CI: $0.08 ; 3.58)$.

In the fatigue patients a low oxygen extraction $(\leq 10 \mathrm{ml} /$ $100 \mathrm{ml}$ ) coincided with a increased response time of $2.35 \pm$ 0.19 versus $1.79 \pm 0.13(P=0.001,95 \%$ CI: $-1.19 ;-0.33)$ in the Shifting Attentional test visual of the ANT. 
Table 1 Demographic data and results

\begin{tabular}{|c|c|c|c|c|c|}
\hline \multicolumn{6}{|l|}{ Female } \\
\hline & & \multirow{2}{*}{$\begin{array}{l}\text { CFS } \\
n=178\end{array}$} & \multirow{2}{*}{$\begin{array}{l}\text { CFI } \\
n=172\end{array}$} & \multirow{2}{*}{$\begin{array}{l}\text { Healthy } \\
n=11\end{array}$} & \multirow{2}{*}{$\begin{array}{l}\text { ANOVA } \\
P\end{array}$} \\
\hline & & & & & \\
\hline Age & (years) & $37.3 \pm 12.1$ & $37.9 \pm 12.3$ & $42.2 \pm 14.8$ & 0.421 \\
\hline Weight & $(\mathrm{kg})$ & $69.5 \pm 15.0$ & $67.5 \pm 13.1$ & $68.6 \pm 13.2$ & 0.412 \\
\hline BSA & $\left(m^{2}\right)$ & $1.81 \pm 0.20$ & $1.78 \pm 0.18$ & $1.79 \pm 0.17$ & 0.497 \\
\hline Haemoglobin & $(\mathrm{mmol} / \mathrm{l})$ & $8.45 \pm 0.55$ & $8.46 \pm 0.51$ & & 0.846 \\
\hline \multicolumn{6}{|l|}{ Rest } \\
\hline $\mathrm{HR}$ & (beats/min) & $96.1 \pm 14.9$ & $93.5 \pm 16.8$ & $87.7 \pm 11.1$ & 0.113 \\
\hline $\mathrm{V}^{\prime} \mathrm{O}_{2}$ & $(\mathrm{ml} / \mathrm{min} / \mathrm{kg})$ & $5.46 \pm 0.99$ & $5.41 \pm 0.93$ & $5.18 \pm 0.98$ & 0.635 \\
\hline $\mathrm{O}_{2}$ pulse & (ml/beat) & $4.00 \pm 0.85$ & $3.95 \pm 0.82$ & $4.09 \pm 0.90$ & 0.784 \\
\hline RER & & $0.86 \pm 0.07$ & $0.86 \pm 0.07$ & $0.81 \pm 0.03$ & 0.073 \\
\hline$V^{\prime} E / N^{\prime} \mathrm{CO}_{2}$ & & $34.2 \pm 4.3$ & $34.3 \pm 4.1$ & $34.7 \pm 3.0$ & 0.924 \\
\hline SVI & $\left(\mathrm{ml} / \mathrm{m}^{2}\right)$ & $42.8 \pm 7.0$ & $42.3 \pm 7.6$ & $43.4 \pm 10.4$ & 0.797 \\
\hline Cardiac index & $\left(\mathrm{L} / \mathrm{min} / \mathrm{m}^{2}\right)$ & $4.10 \pm .081$ & $3.97 \pm 0.92$ & $3.80 \pm 0.95$ & 0.294 \\
\hline $\mathrm{O}_{2}$ extraction & $(\mathrm{ml} / 100 \mathrm{ml})$ & $6.48 \pm 1.65$ & $6.58 \pm 1.72$ & $6.96 \pm 1.63$ & 0.620 \\
\hline \multicolumn{6}{|c|}{ Anaerobic threshold } \\
\hline $\mathrm{HR}$ & (beats/min) & $112.0 \pm 15.6$ & $112.3 \pm 15.2$ & $113.3 \pm 8.7$ & 0.955 \\
\hline $\mathrm{V}^{\prime} \mathrm{O}_{2}$ & $(\mathrm{ml} / \mathrm{min} / \mathrm{kg})$ & $10.9 \pm 2.6$ & $11.6 \pm 2.7$ & $13.7 \pm 3.6$ & 0.001 \\
\hline $\mathrm{O}_{2}$ pulse & (ml/beat) & $6.75 \pm 1.63$ & $6.95 \pm 1.67$ & $8.33 \pm 2.31$ & 0.009 \\
\hline RER & & $0.84 \pm 0.07$ & $0.85 \pm 0.08$ & $0.81 \pm 0.06$ & 0.216 \\
\hline$V^{\prime} E / N^{\prime} \mathrm{CO}_{2}$ & & $29.7 \pm 3.5$ & $28.8 \pm 3.5$ & $27.6 \pm 1.7$ & 0.025 \\
\hline SVI & $\left(\mathrm{ml} / \mathrm{m}^{2}\right)$ & $45.7 \pm 7.9$ & $45.0 \pm 8.2$ & $48.2 \pm 11.8$ & 0.382 \\
\hline Cardiac index & $\left(\mathrm{L} / \mathrm{min} / \mathrm{m}^{2}\right)$ & $5.12 \pm 1.10$ & $5.11 \pm 1.21$ & $5.52 \pm 1.64$ & 0.534 \\
\hline $\mathrm{O}_{2}$ extraction & $(\mathrm{ml} / 100 \mathrm{ml})$ & $8.30 \pm 2.08$ & $8.77 \pm 2.23$ & $9.86 \pm 2.37$ & 0.019 \\
\hline \multicolumn{6}{|l|}{ Peak exercise } \\
\hline $\mathrm{HR}$ & (beats/min) & $158.4 \pm 19.3$ & $159.6 \pm 18.6$ & $164.1 \pm 11.3$ & 0.250 \\
\hline$V^{\prime} \mathrm{O}_{2}$ & $(\mathrm{ml} / \mathrm{min} / \mathrm{kg})$ & $20.3 \pm 5.0$ & $22.2 \pm 5.3$ & $27.4 \pm 7.2$ & 0.000 \\
\hline $\mathrm{V}^{\prime} \mathrm{O}_{2} /$ pred. & $\%$ & $80.6 \pm 17.9$ & $83.1 \pm 18.0$ & $105.4 \pm 18.8$ & 0.000 \\
\hline $\mathrm{O}_{2}$ pulse & (ml/beat) & $8.89 \pm 2.17$ & $9.26 \pm 2.08$ & $11.36 \pm 2.89$ & 0.001 \\
\hline RER & & $1.16 \pm 0.10$ & $1.18 \pm 0.10$ & $1.20 \pm 0.11$ & 0.094 \\
\hline$V^{\prime} E N^{\prime} C_{2}$ & & $30.2 \pm 3.7$ & $29.7 \pm 3.7$ & $27.9 \pm 2.4$ & 0.103 \\
\hline SVI & $\left(\mathrm{ml} / \mathrm{m}^{2}\right)$ & $45.9 \pm 7.9$ & $45.4 \pm 8.3$ & $47.6 \pm 11.2$ & 0.797 \\
\hline Cardiac index & $\left(\mathrm{L} / \mathrm{min} / \mathrm{m}^{2}\right)$ & $7.33 \pm 1.77$ & $7.39 \pm 1.78$ & $7.87 \pm 1.96$ & 0.618 \\
\hline $\mathrm{O}_{2}$ extraction & $(\mathrm{ml} / 100 \mathrm{ml})$ & $10.83 \pm 2.80$ & $11.62 \pm 2.90$ & $13.45 \pm 2.72$ & 0.001 \\
\hline \multicolumn{6}{|l|}{ Slope } \\
\hline$\Delta \mathrm{Q}^{\prime} / \Delta \mathrm{V}^{\prime} \mathrm{O}_{2}$ & $(\mathrm{~L} / \mathrm{L})$ & $7.35 \pm 2.40$ & $6.80 \pm 1.99$ & $5.85 \pm 1.23$ & 0.012 \\
\hline \multicolumn{6}{|l|}{ Male } \\
\hline & & CFS & CFI & Healthy & ANOVA \\
\hline & & $\mathrm{n}=\mathbf{2 5}$ & $\mathrm{n}=51$ & $n=7$ & $P$ \\
\hline Age & (years) & $41.6 \pm 12.3$ & $41.8 \pm 9.9$ & $49.4 \pm 13.8$ & 0.215 \\
\hline Weight & $(\mathrm{kg})$ & $88.9 \pm 15.7$ & $80.0 \pm 12.8$ & $94.3 \pm 13.9$ & 0.005 \\
\hline BSA & $\left(m^{2}\right)$ & $2.12 \pm 0.21$ & $2.02 \pm 0.17$ & $2.19 \pm 0.16$ & 0.016 \\
\hline Haemoglobin & $(\mathrm{mmol} / \mathrm{l})$ & $9.34 \pm 0.66$ & $9.53 \pm 0.56$ & & 0.263 \\
\hline
\end{tabular}


Table 1 Demographic data and results (Continued)

\begin{tabular}{|c|c|c|c|c|c|}
\hline \multicolumn{6}{|l|}{ Rest } \\
\hline$H R$ & (beats/min) & $89.5 \pm 15.8$ & $88.4 \pm 15.1$ & $79.4 \pm 16.2$ & 0.303 \\
\hline $\mathrm{V}^{\prime} \mathrm{O}_{2}$ & $(\mathrm{ml} / \mathrm{min} / \mathrm{kg})$ & $5.08 \pm 0.81$ & $5.51 \pm 0.90$ & $4.57 \pm 0.79$ & 0.093 \\
\hline $\mathrm{O}_{2}$ pulse & (ml/beat) & $5.24 \pm 1.20$ & $5.01 \pm 0.94$ & $5.56 \pm 1.47$ & 0.025 \\
\hline RER & & $0.84 \pm 0.07$ & $0.88 \pm 0.08$ & $0.87 \pm 0.04$ & 0.226 \\
\hline$V^{\prime} E N^{\prime} \mathrm{CO}_{2}$ & & $33.6 \pm 4.4$ & $34.4 \pm 5.7$ & $36.5 \pm 3.0$ & 0.436 \\
\hline SVI & $\left(\mathrm{ml} / \mathrm{m}^{2}\right)$ & $43.4 \pm 8.0$ & $45.9 \pm 6.9$ & $41.2 \pm 6.7$ & 0.182 \\
\hline Cardiac index & $\left(\mathrm{L} / \mathrm{min} / \mathrm{m}^{2}\right)$ & $3.86 \pm 0.83$ & $4.05 \pm 0.96$ & $3.31 \pm 1.02$ & 0.152 \\
\hline $\mathrm{O}_{2}$ extraction & $(\mathrm{ml} / 100 \mathrm{ml})$ & $6.96 \pm 1.76$ & $6.70 \pm 1.68$ & $8.20 \pm 2.82$ & 0.124 \\
\hline \multicolumn{6}{|c|}{ Anaerobic threshold } \\
\hline$H R$ & (beats/min) & $103.6 \pm 14.6$ & $107.0 \pm 14.3$ & $102.1 \pm 19.2$ & 0.529 \\
\hline $\mathrm{V}^{\prime} \mathrm{O}_{2}$ & $(\mathrm{ml} / \mathrm{min} / \mathrm{kg})$ & $11.8 \pm 2.8$ & $13.4 \pm 3.3$ & $13.7 \pm 3.1$ & 0.093 \\
\hline $\mathrm{O}_{2}$ pulse & (ml/beat) & $9.97 \pm 2.50$ & $9.92 \pm 2.49$ & $12.8 \pm 3.5$ & 0.025 \\
\hline RER & & $0.84 \pm 0.09$ & $0.87 \pm 0.06$ & $0.86 \pm 0.08$ & 0.250 \\
\hline$V^{\prime} E N^{\prime} \mathrm{CO}_{2}$ & & $28.0 \pm 3.6$ & $26.2 \pm 3.0$ & $27.3 \pm 3.1$ & 0.089 \\
\hline SVI & $\left(\mathrm{ml} / \mathrm{m}^{2}\right)$ & $47.5 \pm 8.9$ & $51.3 \pm 7.0$ & $45.7 \pm 6.4$ & 0.049 \\
\hline Cardiac index & $\left(\mathrm{L} / \mathrm{min} / \mathrm{m}^{2}\right)$ & $4.95 \pm 1.09$ & $5.48 \pm 1.07$ & $4.77 \pm 1.44$ & 0.082 \\
\hline $\mathrm{O}_{2}$ extraction & $(\mathrm{ml} / 100 \mathrm{ml})$ & $9.86 \pm 2.02$ & $9.74 \pm 3.09$ & $13.0 \pm 4.32$ & 0.025 \\
\hline \multicolumn{6}{|l|}{ Peak exercise } \\
\hline$H R$ & (beats/min) & $154.6 \pm 19.4$ & $160.5 \pm 20.6$ & $151.4 \pm 16.2$ & 0.328 \\
\hline $\mathrm{V}^{\prime} \mathrm{O}_{2}$ & $(\mathrm{ml} / \mathrm{min} / \mathrm{kg})$ & $24.0 \pm 7.2$ & $28.9 \pm 7.1$ & $27.3 \pm 3.7$ & 0.019 \\
\hline $\mathrm{V}^{\prime} \mathrm{O}_{2} /$ pred. & $\%$ & $73.9 \pm 17.5$ & $83.4 \pm 19.2$ & $96.2 \pm 11.4$ & 0.011 \\
\hline $\mathrm{O}_{2}$ pulse & (ml/beat) & $13.5 \pm 3.0$ & $14.2 \pm 3.0$ & $17.1 \pm 3.0$ & 0.023 \\
\hline RER & & $1.19 \pm 0.11$ & $1.24 \pm 0.12$ & $1.29 \pm 0.06$ & 0.100 \\
\hline$V^{\prime} E N^{\prime} C_{2}$ & & $28.9 \pm 5.2$ & $27.9 \pm 3.8$ & $29.2 \pm 4.0$ & 0.537 \\
\hline SVI & $\left(\mathrm{ml} / \mathrm{m}^{2}\right)$ & $47.4 \pm 10.5$ & $50.4 \pm 9.4$ & $44.4 \pm 8.6$ & 0.182 \\
\hline Cardiac index & $\left(\mathrm{L} / \mathrm{min} / \mathrm{m}^{2}\right)$ & $7.44 \pm 2.13$ & $8.02 \pm 2.07$ & $6.45 \pm 1.81$ & 0.136 \\
\hline $\mathrm{O}_{2}$ extraction & $(\mathrm{ml} / 100 \mathrm{ml})$ & $13.66 \pm 3.31$ & $14.63 \pm 4.38$ & $19.52 \pm 6.53$ & 0.008 \\
\hline \multicolumn{6}{|l|}{ Slope } \\
\hline$\Delta \mathrm{Q}^{\prime} / \Delta \mathrm{V}^{\prime} \mathrm{O}_{2}$ & $(\mathrm{~L} / \mathrm{L})$ & $5.84 \pm 1.82$ & $5.38 \pm 1.63$ & $4.01 \pm 1.26$ & 0.043 \\
\hline
\end{tabular}

Demographic data and results of cardiopulmonary exercise tests in patients with chronic fatigue syndrome, idiopathic chronic fatigue and healthy humans during rest, at the anaerobic threshold and maximal workload. BSA: body surface area, $\mathrm{HR}$ : heart rate, $\mathrm{V}^{\prime} \mathrm{O}_{2}$ : oxygen uptake, $\mathrm{V}^{\prime} \mathrm{O}_{2} /$ pred.: oxygen uptake as percentage of predicted, $\mathrm{SVI}$ stroke volume index, $\Delta \mathrm{Q}^{\prime} / \Delta \mathrm{V}^{\prime} \mathrm{O}_{2}$ : increase of cardiac output relative to the increase of oxygen uptake.

\section{Discussion}

The lower maximal exercise capacity (peak $\mathrm{V}^{\prime} \mathrm{O}_{2}$ ) of CFS and CFI patients was related to a lower oxygen uptake of the muscle cells $\left(\mathrm{C}(\mathrm{a}-\mathrm{v}) \mathrm{O}_{2}\right)$ and a higher increase of cardiac output relative to $\mathrm{V}^{\prime} \mathrm{O}_{2}\left(\Delta \mathrm{Q}^{\prime} / \Delta \mathrm{V}^{\prime} \mathrm{O}_{2}\right)$ than in healthy men and women.

The lower peak $\mathrm{V}^{\prime} \mathrm{O}_{2}$ was not explained by an impairment of ventilation. The stroke volume and cardiac output increased during the exercise test, but at no level of effort a consistent difference was seen between the three groups, indicating a normal adaptation of the heart to increasing workload in CFS patients. This result was in accordance with previous studies $[2,4,19]$. Stroke volume in men $(n=83)$ during exercise test was not different from reported values by Nexfin [17], gas rebreathing [5] and impedance cardiography [20]. Resting values were $78.9 \pm 12.8 \mathrm{ml}$ in this study, $80 \pm 9 \mathrm{ml}$ by Nexfin and $73.8 \pm 10.1 \mathrm{ml}$ by impedance cardiography and at peak $100.7 \pm 18.0 \mathrm{ml}$ in this study, $107.5 \pm 7.2 \mathrm{ml}$ by gas rebreathing and $97.9 \pm 6.4 \mathrm{ml}$ by impedance cardiography. Peak cardiac output in men was $192.0 \pm 92.9 \mathrm{ml} / \mathrm{kg} / \mathrm{min}$ in this study and $212 \pm 37 \mathrm{ml} / \mathrm{kg} / \mathrm{min}$ by acetylene rebreathing [6].

We have no haemoglobin data of the healthy visitors. It is possible that the haemoglobin values of patients, although within normal limits [21], were lower than the values of healthy visitors. The mean value of the healthy female visitors would need to be $\pm 10 \mathrm{mmol} / \mathrm{l}(1 \mathrm{mmol}$ 
$\mathrm{Hb} \approx 1.5 \mathrm{ml} / 100 \mathrm{ml} \mathrm{O} 2$ extraction) to explain the difference of $\mathrm{O} 2$ extraction by a difference of haemoglobin [15]. A high cardiac index, caused by low haemoglobin would also have been present during rest [22], but we found no difference between the 3 groups. In men haemoglobin correlated with oxygen extraction, but explained only $6 \%$ of the variance at peak V'O2.

The oxygen extraction increases during incremental exercise and a lower value of peak oxygen extraction in the CFS and CFI groups might be attributed to insufficient effort, caused by lack of motivation. This, however, would not explain the lower oxygen extraction at the anaerobic threshold and the higher slope of the $\Delta Q^{\prime}$ ' $\Delta \mathrm{V}^{\prime} \mathrm{O}_{2}$. Another cause for the lower $\mathrm{V}^{\prime} \mathrm{O}_{2}$ in CFS and CFI could be the deconditioning in these patients, but the value of the increase of cardiac output relative to the oxygen uptake $\left(\Delta \mathrm{Q}^{\prime} / \Delta \mathrm{V}^{\prime} \mathrm{O}_{2}\right)$ is independent from motivation and deconditioning [6] (normal $\Delta Q^{\prime} / \Delta \mathrm{V}^{\prime} \mathrm{O}_{2} \approx 5$ ).

The most probable cause for the low peak $\mathrm{V}^{\prime} \mathrm{O}_{2}$, the low oxygen extraction and the high $\Delta Q^{\prime} / \Delta V^{\prime} \mathrm{O}_{2}$ in CFS and CFI patients was an attenuated cell metabolism. The low oxygen extraction during exercise was also reported in mitochondrial pathology [6], systemic lupus erythematosus [23], HIV [5] and myophosphorylase deficiency [24].

This result is also not in contradiction to the abnormal proton handling that was reported during and after cessation of exercise in CFS patients [25,26].

The peak oxygen extraction in men and women who performed at the same level or better than the reference population of sedentary healthy subjects [27] was never less than $10 \mathrm{ml} / 100 \mathrm{ml}$ as reported for healthy male subjects [28] (Figure 1). The same lower limit of $10 \mathrm{ml} /$ $100 \mathrm{ml}$ was also reported in heart failure patients [29]. The $\mathrm{O}_{2}$ extraction of healthy participants in this study was higher than $10 \mathrm{ml} / 100 \mathrm{ml}$ (Figure 1). The mean $\mathrm{O}_{2}$ extraction at maximal workload in fatigue patients was much lower and comparable to asymptomatic HIV infected individuals $(10.8 \pm 0.5 \mathrm{ml} / 100 \mathrm{ml})$ [5].

The peak $\mathrm{V}^{\prime} \mathrm{O}_{2}$ of 73 CFS patients and 59 CFI patients was the same as or higher than the mean peak $\mathrm{V}^{\prime} \mathrm{O}_{2}$ of healthy sedentary people [27]. All CFS and CFI patients, however, experienced a physical impairment that was severe enough for the diagnosis. The conclusion must be that the subjective experience of physical impairment and the objective peak $\mathrm{V}^{\prime} \mathrm{O}_{2}$ in the CPET are not identical.

If the mitochondrial system is intact in CFS patients [4], the low oxygen extraction in a subgroup of CFS patients may indicate a downregulation of the activity in vivo. A downregulation by a factor that is involved in the activity of the immune system would explain the same phenomenon in SLE [23], different from damaged mitochondria in HIV $[5,30]$. The lower oxygen extraction and higher $\Delta Q^{\prime} / \Delta V^{\prime} O_{2}$ however do not differentiate between down regulation of cell metabolism and congenital

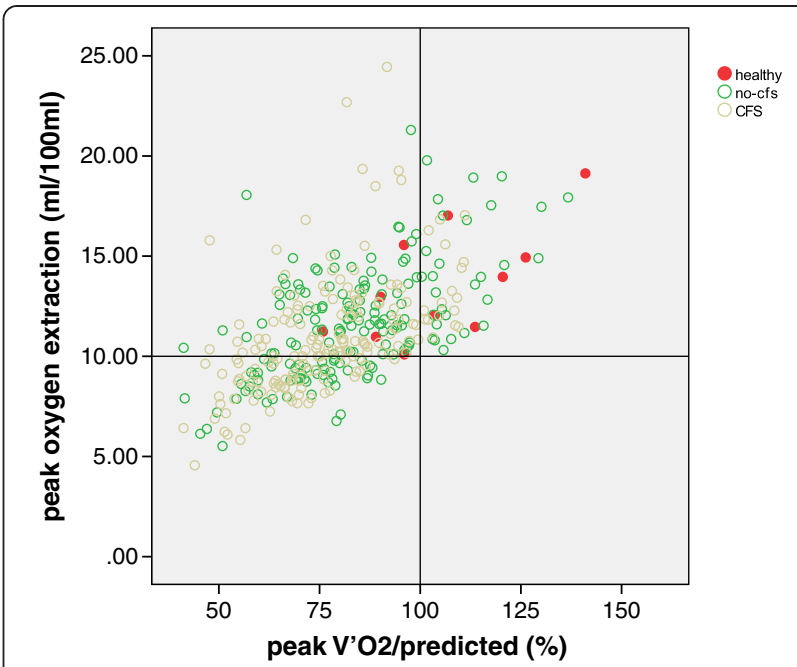

Figure 1 The peak oxygen uptake as percentage of predicted relative to the peak oxygen extraction. Vertical line: predicted peak oxygen uptake. Horizontal line: lowest oxygen extraction reported for healthy humans. No-CFS: Idiopathic Chronic Fatigue, CFS Chronic Fatigue Syndrome.

or acquired mitochondrial pathology in CFS patients. The abnormal results of the Shifting Attentional test visual of the ANT suggest that the impaired oxygen uptake is not limited to the muscle cells.

\section{Limitations}

The validity of the results of this retrospective observational study is limited by the uncontrolled inclusion of the participants. The exercise protocol for healthy visitors was not different from the protocol for fatigued patients but we have no laboratory data of healthy visitors. Therefore we cannot exclude less than optimal results in this group due to unknown diseases. The accuracy and precision of the assessment of stroke volume by Nexfin in CFS patients during CPET was not reported yet. For accuracy we used the data of comparable studies in healthy subjects, the results of a study of repeated CPET's is needed for the assessment of precision. We cannot exclude influence of haemoglobin on the oxygen transport capacity of the blood in healthy visitors.

\section{Conclusions}

CPET with continuous measuring of cardiac output by Nexfin allowed for the calculation of the presence and severity of metabolic causes of exercise intolerance. This retrospective study showed that a low oxygen extraction and a high $\Delta \mathrm{Q}^{\prime} / \Delta \mathrm{V}^{\prime} \mathrm{O}_{2}$ were consistent with a metabolic cause for exercise intolerance in $70 \%$ of CFS patients.

\section{Competing interests}

The authors declare that they do not have competing interests. 


\section{Authors' contributions}

RV and IV contributed to the collection and analysis of the data. The first drafts of the paper were written by RV and RV and IV contributed to the final version of the article. Both authors read and approved the final manuscript.

\section{Acknowledgements}

We thank Corine Reurts-Post for her aid in the collection and administration of the data.

Received: 27 September 2013 Accepted: 22 January 2014

Published: 23 January 2014

\section{References}

1. Fukuda K, Straus SE, Hickie I, Sharpe MC, Dobbins JG, Komaroff A, Schluederberg A, Jones JF, Lloyd AR, Wessely S, et al: The chronic fatigue syndrome: a comprehensive approach to its definition and study. Ann Intern Med 1994, 121(12):953-959.

2. VanNess JM, Snell CR, Strayer DR, Dempsey L IV, Stevens SR: Subclassifying chronic fatigue syndrome through exercise testing. Med Sci Sports Exerc 2003, 35(6):908-913.

3. VanNess JM, Snell CR, Stevens SR, Gibbons R, Keller B: Impaired aerobic metabolism 24-hours post exercise in chronic fatigue syndrome. In The seventh international conference on chronic fatigue syndrome and fibromyalgia. Madison WI: USA; 2004

4. Vermeulen RCW, Kurk RM, Visser FC, Sluiter W, Scholte HR: Patients with chronic fatigue syndrome performed worse than controls in a controlled repeated exercise study despite a normal oxidative phosphorylation capacity. J Trans/ Med 2010, 8:93.

5. Cade W, Fantry LE, Nabar SR, Keyser RE: Decreased peak arteriovenous oxygen difference during treadmill exercise testing in individuals infected with the human immunodeficiency virus. Arch Phys Med Rehabil 2003, 84(11):1595-1603.

6. Taivassalo T, Dysgaard Jensen T, Kennaway N, DiMauro S, Vissing J, Haller RG: The spectrum of exercise tolerance in mitochondrial myopathies: a study of 40 patients. Brain 2003, 126:413-423.

7. Smits B, van den Heuvel L, Knoop H, Kusters B, Janssen A, Borm G, Bleijenberg $G$, Rodenburg $R$, van Engelen B: Mitochondrial enzymes discriminate between mitochondrial disorders and chronic fatigue syndrome. Mitochondrion 2011, 11(5):735-738.

8. Vernon SD, Whistler T, Cameron B, Hickie IB, Reeves WC, Lloyd A: Preliminary evidence of mitochondrial dysfunction associated with post-infective fatigue after acute infection with Epstein Barr virus. BMC Infect Dis 2006, 6:7.

9. Myhill S, Booth NE, McLaren-Howard J: Chronic fatigue syndrome and mitochondrial dysfunction. Int J Clin Exp Med 2009, 2(1):1-16.

10. Poca-Dias V, Ojanguren Saban I, Pereira Dos Santos C, Sanchez-Vizcaino E, Ariza Fernandez A, Garcia-Fructuoso F: Implicación de la mitocondria en la fatiga crónica. DOLOR 2008, 23(1):18-24.

11. Vercoulen JHHM, Alberts M, Bleijenberg G: The Checklist Individual Strength (CIS). Gedragstherapie 1999, 32:31-36.

12. Jason L, Brown M, Evans M, Anderson V, Lerch A, Brown A, Hunnell J, Porter N: Measuring substantial reductions in functioning in patients with chronic fatigue syndrome. Disabil Rehabil 2011, 33(7):589-598.

13. Vermeulen RCW: Translation and validation of the Dutch language version of the CDC symptom Inventory for assessment of Chronic Fatigue Syndrome (CFS). Population Health Metrics 2006, 4:12

14. De Sonneville LMJ: Amsterdam Neuropsychological Tasks: a computeraided assessment program. In Cognitive ergonomics, clinical assessment and computer-assisted learning: Computers in Psychology, Volume 6. Edited by Den Brinker BPLM, Beek PJ, Brand AN, Maarse SJ, Mulder LJM. Lisse: Swets \& Zeitlinger; 1999:187-203.

15. Wassermann K, Hansen JE, Sue DY, Stringer WW, Sietsema KE, Sun X-G Whipp BJ: Exercise testing and Interpretation. Fifth ednth edition. Philadelphia, Baltimore, New York, London, Buenos Aires, Hong Kong, Syndey: Tokyo Wolters Kluwer, Lippingcott Williams \& Wilkins; 2012.

16. Gläser S, Koch B, Ittermann T, Schäper C, Dörr M, Felix SB, Völzke H, Ewert $R$ Hansen JE: Influence of age, sex, body size, smoking, and $\beta$ blockade on key gas exchange exercise parameters in an adult population. Eur $J$ Cardiovasc Prev Rehabil 2009, 17:469-476.

17. Bartels SA, Stok WJ, Bezemer R, Boksem RJ, van Goudoever J, Cherpanath TG, van Lieshout JJ, Westerhof BE, Karemaker JM, Ince C
Noninvasive cardiac output monitoring during exercise testing: Nexfin pulse contour analysis compared to an inert gas rebreathing method and respired gas analysis. J Clin Monit Comput 2011, 25(5):315-321.

18. Martin WH, Montgomery J, Snell PG, Corbett JR, Sokolov JJ, Buckey JC, Maloney DA, Blomqvist CG: Cardiovascular adaptations to intense swim training in sedentary middle-aged men and women. Circulation 1987, 75(3):323-330.

19. VanNess JM, Snell CR, Fredrickson DM, Strayer DR, Stevens SR: Assessment of functional impairment by cardiopulmonary exercise testing in patients with chronic fatigue syndrome. J Chronic Fatigue Syndrome 2001, 8(3-4):103-109.

20. Crisafulli A, Tangianu F, Tocco F, Concu A, Mameli O, Mulliri G, Caria MA: Ischemic preconditioning of the muscle improves exercise performance but not maximal oxygen uptake in humans. $\int \mathrm{App} /$ Physiol 2011, 111:530-536.

21. Nederlandse Vereniging voor Hematologie: Normal values. http://www. hematologienederland.nl/normaalwaarden

22. Woodson RD, Wills RE, Lenfant C: Effect of acute and established anemia on $\mathrm{O} 2$ transport at rest, submaximal and maximal work. J Appl Physiol Respir Envir Exerc Physol 1978, 44(1):36-43.

23. Sakauchi M, Matsumara T, Yamaoka T, Koami T, Shibata M, Nakamura M, Watanabe R, Kaneko K, Kato S, Sequchi H, et al: Reduced muscle uptake of oxygen during exercise in patients with systemic lupus erythematosus. J Rheumatol 1995, 22(8):1483-1487.

24. Haller RG, Lewis SF, Cook JD, Blomqvist CG: Myophosphorylase deficiency impairs muscle oxidative metabolism. Ann Neurol 2004, 17(2):196-199.

25. Jones DEJ, Hollingsworth KG, Taylor R, Blamire AM, Newton JL: Abnormalities in $\mathrm{pH}$ handling by peripheral muscle and potential regulation by the autonomic nervous system in chronic fatigue syndrome. J Intern Med 2010, 267(4):394-401.

26. Jones DEJ, Hollingsworth KG, Jakovljevic DG, Fattakhova G, Pairman J, Blamire AM, Trenell MI, Newton JL: Loss of capacity to recover from acidosis on repeat exercise in chronic fatigue syndrome: a case-control study. Eur J Clin Invest 2011, 42(2):186-194

27. Koch B, Schäper C, Ittermann T, Spielhagen T, Dörr M, Völzke H, Opitz CF, Ewert $R, G$ Gläser $S$ : Reference values for cardiopulmonary exercise testing in healthy volunteers: the SHIP study. Eur Respir J 2009, 33(2):389-397.

28. Stringer WW, Hansen JE, Wasserman K: Cardiac output estimated noninvasively from oxygen uptake during exercise. J App/ Physiol 1997, 82(3):908-912

29. Agostoni PG, Wasserman K, Perego GB, Guazzi M, Cattadori G, Palermo P, Lauri G, Marenzi G: Non-invasive measurement of stroke volume during exercise in heart failure patients. Clin Sci (London) 2000, 98(5):545-551.

30. Pothoff $\mathrm{G}$, Wasserman $\mathrm{K}$, Ostmann $\mathrm{H}$ : Impairment of exercise capacity in various groups of HIV-infected patients. Respiration 1994, 61:80-85.

doi:10.1186/1479-5876-12-20

Cite this article as: Vermeulen and Vermeulen van Eck: Decreased oxygen extraction during cardiopulmonary exercise test in patients with chronic fatigue syndrome. Journal of Translational Medicine 2014 12:20.

\section{Submit your next manuscript to BioMed Central and take full advantage of:}

- Convenient online submission

- Thorough peer review

- No space constraints or color figure charges

- Immediate publication on acceptance

- Inclusion in PubMed, CAS, Scopus and Google Scholar

- Research which is freely available for redistribution 